\title{
MENINGKATKAN HASIL BELAJAR SISWA MENERAPKAN MODEL MAKE A MACTH MATA PELAJARAN IPS POKOK BAHASAN MENCERITAKAN TOKOH TOKOH SEJARAH PADA MASA HINDU- BUDHA DAN ISLAM DI INDONESIA DI KELAS VI SD NEGER0 040451 KABANJAHE TP 2018/2019
}

\author{
Pelista Br Karo Sekali ${ }^{1)}$ Jainab $^{2)}$ \\ (Dosen FKIP PGSD Universitas Quality)
}

\begin{abstract}
Penelitian tindakan kelas ini dilaksanakan menerapkan Model Pembelajaran Make a Macth Mata Pelajaran IPS Pokok Bahasan Menceritakan Tokoh-tokoh Sejaran pada Masa Hindu Budha dan Islam di Indonesia di Kelas VI SD Negeri 040451 Kabanjahe Tahun Pelajaran 2018/2019.

Tujuan penelitian ini adalah untuk mengetahui Pelaksanaan Pembelajaran siswa, mengetahui ketuntasan belajar siswa, mengetahui peningkatan hasil belajar siswa menerapkan Model Make a Match Mata Pelajaran IPS Pokok Bahasan Menceritakan Tokoh-tokoh Sejarah pada Masa Hindu Budha dan Islam di Indonesia di Kelas VI SD Negeri 040451 Kabanjahe Tahun Pelajaran 2018/2019.Subjek penelitian ini adalah keas VI berjumlah 30 orang dan objek penelitian menerapkan Model Make a Macth. Istrumen yang digunakan adalah lembar observasi dan test Essai

Berdasarkan hasil penelitian Siklus I diperoleh Pelaksanaan Pembelajaran aktivitas guru $60 \%$ kreteria cukup dan siklus II diperoleh $78 \%$ kreteria baik. , aktivitas siswa siklus I diperoleh nilai 68 termasuk kreteria cukup, dan siklus II nilai aktivitas siswa 84 kreteria baik, Ketuntasan belajar siklus I dari 30 siswa 73 $\%$ atau 22 orang yang tuntas, siklus II 27 orang tuntas belajarnya atau 90\% dan peningkatan hasil belajar $10 \%$ menerapkan Model Pembelajaran Make a Macth Mata Pelajaran IPS Pokok Bahasan Menceritakan Tokoh-tokoh Sejarah pada Masa Hindu Budha dan Islam di Indonesia di Kelas VI SD Negeri 040451 Kabanjahe Tahun Pelajaran 2018/2019.

Dengan demikian penelitian ini dapat disimpulkan bahwa, pelaksanaan pembelajaran berkreteria baik, hasil belajar siswa tuntas secara klsikal dan meningkat menerapkan Model Pembelajaran Make a Macth Mata Pelajaran IPS Pokok Bahasan Menceritakan Tokoh-tokoh Sejaran pada Masa Hindu Budha dan Islam di Indonesia di Kelas VI SD Negeri 040451 Kabanjahe Tahun Pelajaran 2018/2019.
\end{abstract}

Kata kunci : Model pembelajaran Make a Match, Pelaksanaan Pembelajaran, Hasil belajar

\footnotetext{
ABSTRACT

This classroom action research was carried out to apply the Learning Model Make a Macth Social Studies Subject The Subject of Telling Historical Figures in the Hindu Hindu and Islamic Period in Indonesia in Class VI SD Negeri 040451 Kabanjahe Academic Year 2018/2019.

The purpose of this study was to find out the Learning Implementation of students, knowing the mastery of student learning, knowing the improvement in student learning outcomes applying the Model Make a Match Social Studies Subjects Discussing Historical Figures in the Period of Hindu Buddhism and
} 
Islam in Indonesia in Class VI SD Negeri 040451 Kabanjahe Academic Year 2018/2019. The subject of this research is the keas VI totaling 30 people and the research object applies the Make a Macth Model. The instruments used are observation sheets and essay tests.

Based on the results of the Cycle I study, the learning activities of the teacher obtained $60 \%$ sufficient criteria and the second cycle obtained $78 \%$ good criteria. , the activity of students in cycle I was obtained 68 values including sufficient criteria, and cycle II the activity value of students 84 criteria was good, completeness learning cycle I of 30 students $73 \%$ or 22 people completed, cycle II 27 people completed their study or $90 \%$ and increased learning outcomes $10 \%$ apply Learning Model Make a Macth Social Studies Subjects Discuss the Historical Figures in the Hindu Hindu and Islamic Period in Indonesia in Class VI SD Negeri 040451 Kabanjahe 2018/2019 Academic Year.

Thus, this study can be concluded that, the implementation of good performance learning, student learning outcomes are completed thoroughly and increase applying Learning Model Make a Macth Social Sciences Subjects Discussing Historical Figures in the Period of Hindu Buddhism and Islam in Indonesia in Class VI Public Elementary School 040451 Kabanjahe Academic Year 2018/2019.

Keywords: Make a Match learning model, Learning Implementation, Learning Outcomes. 
Berhasil atau tidaknya suatu proses pendidikan sangatlah dipengaruhi oleh pembelajaran yang berlangsung. Proses pembelajaran ini tersusun atas beberapa komponen atau unsur yang saling berkaitan satu sama lain. Unsur tersebut adalah: guru, siswa, bahan/materi, cara/metode, kurikulum pengajaran, sarana belajar, waktu belajar, serta fasilitas belajar. Proses pembelajaran ini juga memiliki interaksi yang langsung antara satu dengan yang lainnya, interaksi yang terjadi pada saat berlangsungnya proses belajar mengajar adalah antara guru dengan siswa, interaksi ini memegang peranan yang penting untuk mencapai suatu tujuan pembelajaran yang kita inginkan.

Dalam proses belajar mengajar yang efektif Guru sebagai salah satu pihak yang bertanggung jawab, dituntut mempersiapkan kegiatan awal sampai akhir pelajaran. Seorang guru yang profesional memiliki kemampuan da 1 menerapkan model pembelaj: yang efektif, memahami model, tepat memilih, terampil menggunakan model dalam pembelajaran. Karena salah satu faktor yang mendukung keberhasilan seorang guru itu yakni guru mampu menerapkan metode atau model pembelajaran yang sesuai dengan materi yang diajarkan.

Keterlibatan siswa yang kreatif kritis, menyenangkan sangat diperlukan dalam sehingga dapat meningkatkan kemampuan siswa dalam belajar. Siswa akan merasakan segala aktifitas dalam belajar menjadi pengalaman yang bermakna. Guru bukan hanya sekedar menyampaikan materi saja, tetapi lebih dari itu guru dapat dikatakan sebagai sentral pembelajaran. Selain guru, siswa juga dituntut aktif dan kreatif dalam proses belajar mengajar. Dengan adanya pembelajaran dua arah antara guru dan siswa, maka hasil belajar siswa akan maksimal.

Banyak pihak termasuk sebagian guru pelajaran IPS, pada Kenyataanya diasosiasikan pelajaran yang bersifat hapalan, siswa berpendapat bahwa belajar IPS itu kurang menarik karena pelajaran IPS yang disajikan guru jarang menggunakan model dan lebih sering menggunakan metode ceramah yang menjadikan siswa hanya duduk, diam, dengar, mencatat dan kurang bertanya sehingga kegiatan belajar mengajar menjadi monoton dan kurang menarik.. Guru juga jarang menggunakan media pada saat mengajar karena media tidak tersedia sehingga siswa jarang termotivasi untuk bertanya.

Akibat permasalahan pembelajaran di atas maka hasil belajar siswa kurang maksimal, karena nilai yang diperoleh siswa belum mencapai standart ketuntasan Nilai Kriteria Ketuntasan Minimal (KKM) pada mata pelajaran IPS di kelas V SD Negeri 040451 adalah 70. Hal ini dapat dilihat pada Tabel 1.1

Untuk mengatasi masalah tersebut peneliti menggunakan model Make a Match. Dalam penerapan model pembelajaran Make amatch siswa diminta mencari pasangan kartu yang merupakan jawaban atau pertanyaan materi tertentu dalam pembelajaran.Model pembelajaran Make a match bertujuan agar siswa mencari pasangan sambil belajar mengenai suatu konsep atau topik dalam suasana yang menyenangkan. Pelaksanaan model make a match harus didukung dengan keaktifan siswa untuk bergerak mencari pasangan dengan kartu yang sesuai 


\section{Tabel 1.1 Data Nilai Mata Pelajaran Kelas V SD Negeri 040451}

\begin{tabular}{|c|c|c|c|c|c|}
\hline \multirow{2}{*}{$\begin{array}{c}\text { Tahun } \\
\text { Pelajaran }\end{array}$} & \multirow{2}{*}{ KKM } & \multirow{2}{*}{$\begin{array}{c}\text { Jumlah } \\
\text { siswa }\end{array}$} & \multicolumn{2}{|c|}{ Jumlah siswa } & Nilai \\
\cline { 4 - 5 } & & Tuntas & $\begin{array}{c}\text { Tidak } \\
\text { tuntas }\end{array}$ & $\begin{array}{c}\text { rata- } \\
\text { rata }\end{array}$ \\
\hline $2018 / 2019$ & 70 & 30 & $18(64,2 \%)$ & $12(42,8 \%)$ & 66 \\
\hline
\end{tabular}

Sumber: Guru Kelas VI SD Negeri 040451

Dengan jawaban atau pertanyaan dalam kartu tersebut. Siswa yang pembelajarannya dengan model make a match aktif dalam mengikuti pembelajaran sehingga dapat mempunyai pengalaman belajar yang bermakna.

Berdasarkan uraian yang disajikan maka, peneliti tertarik untuk mengadakan penelitian dengan judul :"Meningkatkan Hasil Belajar Siswa dengan Menggunakan Model Make a match pada Mata Pelajaran IPS Pokok Bahasan Menceritakan Tokoh-Tokoh Sejarah pada Masa Hindu-Budha, dan Islam di Indonesia di Kelas V SD Negeri 040451 Kabanjahe Tahun Pelajaran 2018/2019

\section{Tujuan Penelitian}

Berdasarkan masalah di atas, maka yang menjadi tujuan penelitian ini adalah :

1. Untuk Mengetahui Pelaksanaan Pembelajaran Menerapkan Model Make a match Pokok Bahasan Menceritakan TokohTokoh Sejarah pada Masa Hindu-Budha, dan Islam di Indonesia di Kelas VI SD Negeri $040451 \quad$ Kabanjahe Tahun Pelajaran 2018/2019

2. Untuk Mengetahui Ketuntasan Belajar dengan Menerapkan Model Make a match Pokok Bahasan
Menceritakan Tokoh-Tokoh Sejarah pada Masa HinduBudha, dan Islam di Indonesia di Kelas VI SD Negeri 040451 Tahun Pelajaran 2018/2019 .

3. Untuk Mengetahui Peningkatan Hasil Belajar Siswa Menerapkan Model Make a match Pokok Bahasan Menceritakan Tokoh-Tokoh Sejarah pada Masa HinduBudha, dan Islam di Indonesia di Kelas VI SD Negeri 040451 Kabanjahe Tahun Pelajaran 2018/2019”.

\section{B. KAJIAN TEORITS}

\section{Pengertian Hasil Belajar}

Pada saat melakukan kegiatan belajar terjadi proses berpikir yang melibatkan kegiatan mental, terjadi penyusunan hubungan informasiinformasi yang diterima sehingga timbul suatu pemahaman dan penguasan terhadap materi yang diberikan. Dengan adanya pemahaman dan penguasaan yang didapat setelah melalui proses belajar mengajar maka siswa telah memahami suatu perubahan dari yang tidak diketahui menjadi diketahui.

$$
\text { Ahmad Susanto,(2014:5) }
$$

menyatakan"Hasil belajar yaitu perubahan-perubahan yang terjadi pada diri siswa, baik yang menyangkut aspek kognitif, afektif dan psikomotor sebagai hasil dari kegiatan belajar. 


\section{Pengertian Model Make A Match}

Menurut Istarani (2011:63) Menyatakan:Hal-hal yang diperlukan dipersiapkan jika pembelajaran dikembangkan dengan Make a match adalah kartu-kartu. Kartu tersebut terdiri dari kartu-kartu berisi pertanyaan-pertanyaan dan katukartu lainnya berisi jawaban dari pertanyaan-pertanyaan tersebut.

\section{Kelebihan dan Kekurangan Model Make A Match}

Kelebihan model Make a match Istarani (2011:65) adalah sebagai berikut:

a. Siswa terlibat langsung dalam menjawab soal yang disampaikan kepadanya memalui kartu.

b. Meningkatkan kereativitas belajar siswa.

c. Menghindari kejenuhan siswa dalam mengikuti proses belajar mengajar.

d. Dapat menumbuhkan kereatifiras berfikir siswa ,sebab melalui pencocokan pertanyaan dan jawaban akan tumbuh tersendirinya.

e. Pembelajaran lebih menyenangkan karena melibatkan media pembelajaran yang digunakan guru.

Kekurangan model Make a match Istarani (2011:65) adalah sebagai berikut:

a. Sulit bagi guru mempersiapkan kartu-kartu yang baik dan bagus.

b. Sulit mengatur ritme atau jalannya peruses pembelajaran.

c. Siswa kurang menyerapi makna pembelajaran yang ingin disampaikan karena siswa merasa hanya sekedar permainan saja. d. Sulit untuk mengkonsentrasikan anak.

\section{Langkah-langkah Make A Match MenurutIstarani (2011:65)}

Langkah-Langkah dari model Make a match adalah sebagai berikut:

a. Guru menyiapkan beberapa kartu yang berisi beberapa konsep atau topik yang cocok untuk sesi review, satu bagian kartu soal dan bagian lainnya kartu jawaban.

b. Setiap peserta didik mendapatkan satu kartu.

c. Tiap peserta didik medapatkan jawaban/soal dari kartu yang dipegang.

d. Setiap peserta didik mencari pasangan yang mempunyai kartu yang cocok dengan kartunya (soal jawaban ).

e. Setiap peserta didik yang dapat mencocokan kartunya sebelum batas waktu diberi poin.

f. Setelah satu babak kartu dicocokkan lagi agar tiap peserta didik mendapat kartu yang berbeda dari sebelumnya.

g. Demikian seterusnya.

h. Kesimpulan /Penutup.

\section{Pelaksanaan Pembelajaran}

Pembelajaran merupakan sesuatu yang kompleks, dimana seorang pendidik tidak hanya menyampaikan pesan kepada peserta didik akan tetapi merupakan aktifitas profesional untuk menciptakan pembelajaran yang kondusif, menantang dan menyenangkan. Untuk mengetahui pelaksanaan PTK ini, digunakan alat penilaian yakni lembar observasi. Lembar observasi berisi tentang pengelolaan 
pembelajaran yang diisi oleh observer.

Kriteria penilaian dalam pelaksanaan pembelajaran aktivitas guru menurut Piet A. Sahertian (2013:61) adalah sebagai berikut :

$$
\mathrm{A} \quad=81-
$$

$100 \%$

..Baik Sekali

$$
\mathrm{B}=
$$

$80 \%$

...Baik

$\mathrm{C}=$

41-

$60 \%$

...Cukup

$\mathrm{D} \quad=21-$

$40 \%$

...Kurang

$$
\mathrm{E} \quad=0 \text { - }
$$

$20 \%$

...Kurang sekali

Kriteria

pembelajaran aktivitas siswa

menurut Asep Jihad (2013:130)

adalah sebagai berikut :

Kurang

1.Nilai $=10-29$ Sangat

2.Nilai $=30-49$ Kurang

3. Nilai $=50-69$ Cukup

4. Nilai $=70-89$ Baik

5. Nilai $=90-100$ Sangat Baik

\section{Ketuntasan Belajar}

Berdasarkan

kriteria

ketuntasan belajar yang telah dinyatakan, Depdikbud dalam Trianto (2011: 241), menyatakan "Setiap siswa yang telah tuntas hasil belajarnya (ketuntasan individu) jika proporsi jawaban benar siswa $\geq 65 \%$, dan suatu kelas dikatakan tuntas belajarnya (ketuntasan klasikal)jika dalam kelas tersebut terdapat $\geq 85 \%$ siswa yang tuntas belajarnya".

\section{Penelitian Tindakan Kelas}

Penelitian Tindakan Kelas adalah penelitian yang dilakukan oleh guru di dalam kelasnya sendiri melalui refleksi diri, dengan tujuan untuk memperbaiki kinerjanya sebagai guru, sehingga hasil belajar siswa menjadi meningkat.

Kemmis dalam H. Wina Sanjaya,(2009:24) menyatakan : "Penelitian tindakan adalah suatu bentuk penelitian reflektif dan kolektif yang dilakukan oleh peneliti dalam situasi sosial untuk meningkatkan penalaran praktik sosial mereka".

Zainal (2008:13) menyatakan : "Penelitian tindakan kelas merupakan suatu pencermatan terhadap kegiatan yang sengaja dimunculkan dan terjadi dalam sebuah kelas".

Haryono

menyatakan : "Penelitian tindakan kelas merupakan tindakan mengumpulkan, mengolah, menganalis, menyimpulkan data untuk menentukan tingkat keberhasilan jenis tindakan yang dilaksanakan oleh guru dalam proses pembelajaran".

Suharsismi dkk (2012:3) menyatakan : "Penelitian tindakan kelas adalah suatu pencermatan terhadap kegiatan belajar berupa sebuah tindakan kelas yang tidak sengaja dimunculkan dan terjadi dalam sebuah kelas secara bersama".

Dari pernyataan di atas dapat dinyatakan bahwa Penelitian Tindakan Kelas (PTK) adalah penelitian yang dilakukan oleh guru di kelasnya sendiri melalui refleksi diri dengan tujuan untuk memperbaiki kinerjanya sehingga hasil belajar siswa meningkat.

\section{Kelebihan dan Keterbatasan PTK}

a. Kelebihan PTK

PTK memiliki kelebihan menurut H. Wina Sanjaya, (2012:37) adalahsebagai berikut : 
1) PTK tidak dilaksanakan oleh seorang saja akan tetapi dilaksanakan secara kolaboratif dengan melibatkan berbagai pihak antara lain guru sebagai pelaksana tindakan sekaligus sebagai peneliti, observasi baik yang dilakukukan oleh guru lain sebagai teman sejawat atau oleh orang lain, ahli peneliti yang biasanya orang-orang LPTK dan siswa itu sendiri.

2) Kerja sama sebagai ciri khas dalam PTK, memungkinkan dapat menghasilkan sesuatu yang lebih kreatif dan inovatif, sebab setiap yang terlibat memiliki kesempatan untuk memunculkan pandangan-pandangan kritisnya.

3) Hasil atau simpulan yang diperoleh adalah hasil kesepakatan semua pihak khususnya antara guru sebagai peneliti dengan mitranya, demikian akan meningkatakan validitas dan reabilitas hasil penelitian.

4) PTK berangkat dari masalah yang dihadapi guru secara nyata, dengan demikian kelebihan PTK adalah hasil yang diperoleh dapat secara langsung diterapkan oleh guru.

\section{Keterbatasan PTK}

Keterbatasan PTK menurut Wina Sanjaya, (2012:38) adalah sebagai berikut:

1) Keterbatasan yang berkaitan dengan aspek peneliti atau guru itu sendiri

2) PTK adalah penelitian yang berangkat dari masalah praktis yang dihadapi oleh guru, dengan demikian simpulan yang dihasilkan tidak bersifat universal yang berlaku secara umum.

3) PTK adalah penelitian yang bersifat situasional dan kondisional, yang bersifat longgar yang kadang-kadang tidak menerapkan prinsipprinsip metode ilmiah secara ajek, dengan demikian banyak orang yang meragukan PTK sebagai suatu kerja penelitian ilmiah.

\section{B. METODOLOGI PENELITIAN}

\section{Desain Penelitian}

Sesuai dengan jenis penelitian ini, yaitu penelitian tindakan kelas maka penelitian ini memiliki tahapan yang berupa siklus. Rancangan masingmasing siklus terdiri dari empat tahap yaitu: perencanaan, pelaksanaan, pengamatan, dan refleksi (Arikunto, 2015: 42).

\section{Teknik Pengumpul Data}

a. Lembar observasi guru dan siswa

Pengamatan atau observasi adalah teknik yang dilakukan dengan cara melakukan pengamatan secara teliti serta pengamatan secara sistematis meliputi aktivitas kinerja guru dan keaktifan siswa dalam pembelajaran IPS menerapkan Model problem solving, tujuannya mengetahui kesesuaian tindakan dengan rencana yang telah disusun dan guna mengetahui sejauhmana pelaksaaan tindakan dapat menghasilkan perubahan yang sesuai dengan yang dikehendaki. 


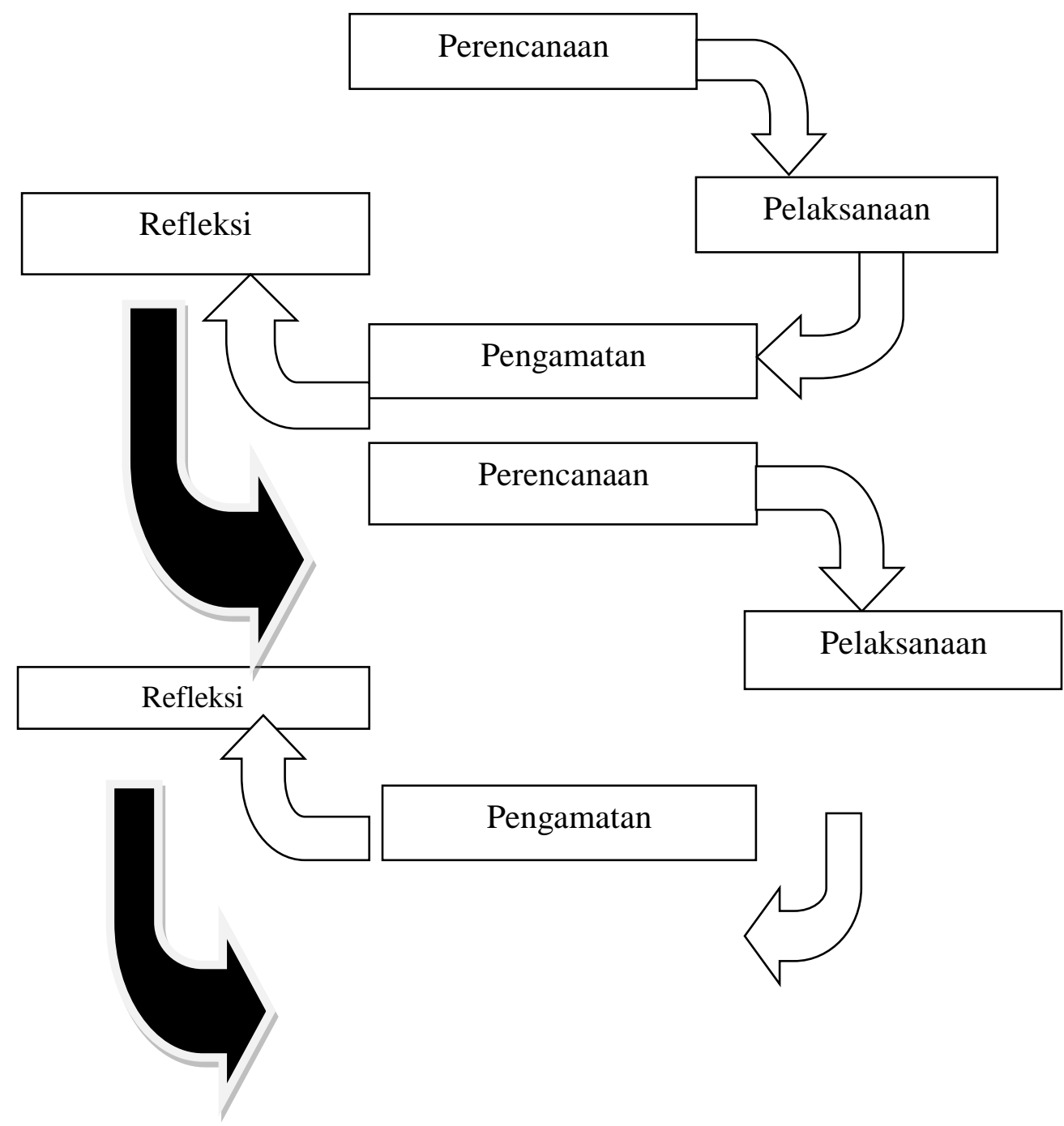

\section{Gambar 3.1: Model PTK Suharsimi Arikunto}

b. Tes

Tes adalah suatu alat atau proses yang sistematis dan objektif untuk memperoleh datadata atau keterangan yang diinginkan seseorang, dengan cara yang boleh dikatakan tepat dan cepat. Tes yang diberikan kepada siswa yaitu tes tertulis dalam bentuk essay test.

\section{Teknik Analisis Data}

Untuk mengetahui keefektifan suatu model dalam kegiatan pembelajaran, perlu dilakukan analisis data. Untuk menganalis data yang diperoleh dari hasil test dapat digunakan rumus:

a. Penilaian Aktifitas Guru

$H P=\frac{\text { Jumlah hasil observasi }}{\text { Jumlah butir pengamatan }}$

( Piet A. Sahertien 2010:61)

b. Penilaian Aktivitas siswa

nilai siswa $=\frac{\text { skor perolehan }}{\text { skor maksimum }} \times 100$

(Jihad dan Haris,2012:131)

c. Ketuntasan Hasil belajar siswa

Ketuntasan Individu

Berdasarkan teori yang telah dibuat, maka untuk mengetahui persentase kemampuan siswa secara individu digunakan rumus sebagai berikut:"' 


$$
\mathrm{KB}=\frac{\mathrm{T}}{\mathrm{Tt}} \times 100 \%
$$

(Trianto,2011:241)

Keterangan :

$\mathrm{KB}$ : Ketuntasan Belajar

$\mathrm{T}$ : Jumlah skor yang diperoleh siswa

$\mathrm{Tt} \quad$ : Skor total

Ketuntasan Klasikal

Persentase ketuntasan

belajar siswa secara klasikal dirumuskan sebagai berikut:

$p=\frac{\sum \text { siswa yang tuntas belajar }}{\sum \text { siswa }} \times 100 \%$

(Zainal

Aqib,2010:41)

Tabel 3. Nilai Rata-rata Hasil Belajar Siswa

\begin{tabular}{|l|l|l|}
\hline Tes & Rata-rata & Peningkatan \\
\hline Siklus I & 76,6 & $10.34 \%$ \\
\cline { 1 - 2 } Siklus II & 87 & \\
\hline
\end{tabular}

dengan demikian penguasaan

kelas dapat terjaga.

Menceritakan Tokoh-Tokoh Sejarah pada Masa Hindu-Budha, dan Islam di Indonesia di Kelas VI SD Negeri 040451 Kabanjahe Tahun Pelajaran 2018/2019

Dalam hal ini secara klasikal hasil belajar siswa pada siklus I belum tuntas karena belum mencapai $\geq 85 \%$ siswa yang tuntas belajarnya

\section{Refleksi Siklus I}

Berdasarkan analisa data siklus I pelaksanaan pembelajaran belum mencapai kreteria baik dan ketuntasan belajar secara klasikal belum mencapai $85 \%$, maka perlu dilanjutkan kembali penelitian tindakan kelas pada siklus II dengan merefleksi aspek aspek pelaksanaan aktivitas guru dan siswa yang belum mencapai kreteria baik. sebagai berikut.

a. Aktivitas Guru

1) Penguasaan kelas, tindakan pada siklus II dengan tepuk PKK

\section{HASIL DAN PEMBAHASAN}

Berdasarkan hasil observasi pada siklus I dari aktivitas guru diperoleh $60 \%$ dan aktivitas siswa diperoleh nilai 68 , dengan demikian pelaksanaan aktivitas pembelajaran untuk aktivitas guru dan siswa masih dalam kriteria cukup. Ketuntasan Hasil Belajar Siswa 73\%(22 siswa) dan sebanyak 27\% (9 siswa) yang tidak tuntas dengan menerapkan Model Make a match Pokok Bahasan
2) Penggunaan model pembelajaran make a match pada proses pembelajaran, tindakan pada siklus II dengan menjelaskan langkah-langkah model pembelajaran make a match sebelum masuk ke inti pembelajaran.

b. Aktivitas Siswa

Ketenangan siswa pada saat belajar, tindakan pada siklus II dengan mengarahkan siswa untuk memperhatikan pertayaan dan kartu jawaban

Berdasarkan data Hasil penelitian siklus II pelaksanaan aktivitas guru adalah $78 \%$ termasuk kreteria baik, aktivitas siswa diperoleh nilai 84 kreteria baik, Ketuntasan hasil belajar mencapai $90 \%$ dengan menerapkan Model Make a match Pokok Bahasan Menceritakan Tokoh-Tokoh Sejarah pada Masa Hindu-Budha, dan Islam di Indonesia di Kelas 
VI SD Negeri 040451 Kabanjahe Tahun Pelajaran 2018/2019. Dalam hal ini secara klasikal hasil belajar siswa pada siklus II sudah tuntas karena telah mencapai $\geq 85 \%$ siswa tuntas belajarnya.

.Peningkatan Hasil Belajar Siswa berdasarkan hasil tes siswa pada siklus I dan siklus II sebagai berikut: Tabel 3

\section{Kesimpulan}

Berdasarkan hasil pembahasan pada Bab IV dapat ditarik kesimpulan bahwa :

1. Pelaksanaan pembelajaran berkreteria baik dengan menerapkan Model Make a match Pokok Bahasan Menceritakan Tokoh-Tokoh Sejarah pada Masa Hindu-Budha, dan Islam di Indonesia di Kelas VI SD Negeri 040451 Kabanjahe Tahun Pelajaran 2018/2019

2. Hasil belajar siswa menerapkan Model Make a match Pokok Bahasan Menceritakan TokohTokoh Sejarah pada Masa HinduBudha, dan Islam di Indonesia di Kelas VI SD Negeri 040451 Kabanjahe Tahun Pelajaran 2018/2019 tuntas secara klasikal.

3. Hasil belajar siswa meningkat menerapkan Model Make a match Pokok Bahasan Menceritakan Tokoh-Tokoh Sejarah pada Masa Hindu-Budha, dan Islam di Indonesia di Kelas VI SD Negeri 040451 Kabanjahe Tahun Pelajaran 2018/2019 tuntas secara klasikal.

\section{DAFTAR PUSTAKA}

Aqib Zainal, 2016. Penelitian Tindakan Kelas. Bandung : CV Yrama Widya.

Arikunto, Suharsimi dkk.2015. Penelitian Tindakan Kelas. Jakarta: Bumi Aksara

Ainurrahman, 2012. Belajar dan Pembelajaran. Bandung : Alfabeta
Dimyati dan Mudjiono, 2016 .Belajar dan Pembelajaran. Jakarta: Rineka Cipta

Fita Nur Arifah, 2017. Penelitian Tindakan Kelas dan Karya Ilmiah Untuk Guru, Araska

Huda, Miftahul. 2014. Model-Model Pengajaran dan pembelajaran. Yogyakarta: Pustaka Pelajar

Jihad, Asep. 2012. Evaluasi Pembelajaran. Yogyakarta: Multi Pressindo

Purwanto. 2011. Evaluasi Hasil Belajar. Yogyakarta: Pustaka Pelajar

Sahaertian.Piet.2013 Konsep Dasar dan Teknik Supervisi Pendidikan dalam Pengembangan Sumber daya Manusia. Jakarta: Rineka Cipta

Sagla, Syaiful. (2013). Konsep dan Makna Pembelajaran, Bandung: CV Alfabeta

Shoimin, Aris. 2014. 68 Model Pembelajaran Inovatif. Yogyakarta: Ar-Ruzz Media

Slameto, 2016. Belajar dan Faktor yang mempengaruhinya. Jakarta: Rineka Cipta

Sujana, 2012. Metode Statistik. Bandung: Tarsito

Sukardi, 2013. Metode Penelitian Tindakan Kelas. Jakarta: PT Aksara

Trianto. 2011. Mendesain Model pembelajaran Inovativ progresif, Jakarta: Prenada Media Group.

Undang -Undang RI No 14 Tahun 2005, 2006, Guru dan Dosen. Jakarta: Ciputat Press 